\title{
THE EFFECTS OF FEEDING TRIACYLGLYCEROLS ON MILK FAT COMPOSITION, LIPOGENESIS AND POLYMER-PROTOMER TRANSITION OF ACETYL-COA CARBOXYLASE IN RAT MAMMARY GLAND
}

\author{
Oben JE ${ }^{* 1}$, Ngondi JL ${ }^{1}$, Agbor GA ${ }^{2}$ and E Enonchong ${ }^{1}$
}

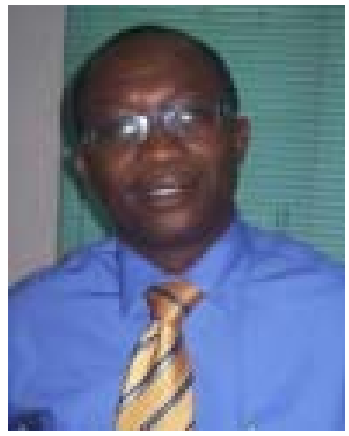

Oben Julius

*Corresponding Author Email: juliusoben@hotmail.com

${ }^{\mathbf{1}}$ Laboratory of Nutrition and Nutritional Biochemistry, Department of Biochemistry, Faculty of Science, BP 812 University of Yaoundé I, Yaoundé, Cameroon.

${ }^{2}$ Institute of Medical Research and Medicinal Plants Studies, Yaoundé, Cameroon 


\section{ABSTRACT}

Diets rich in fats produce large quantities of milk with high lipid concentrations, which may be important for the growth of neonates. The present study investigates the effect of different fat enriched diets on mammary gland lipogenesis in lactating rats. Rats were fed for 6 weeks during pregnancy through to mid-lactation with diets containing chow supplemented with $20 \%$ (w/w) coconut oil, olive oil or corn oil. The control animals were fed with a low fat $(0.5 \%, \mathrm{w} / \mathrm{w})$ diet, or with chow $(6.8 \%, \mathrm{w} / \mathrm{w}$ fat $)$. Rats fed either the $20 \%(\mathrm{w} / \mathrm{w})$ olive oil-supplemented diet or the $20 \%(\mathrm{w} / \mathrm{w})$ corn oil-supplemented diet produced milk with significantly lower total fat concentrations $(p<0.05)$ than rats fed the low-fat $(0.5 \%(\mathrm{w} / \mathrm{w})$ corn oil) control diet or with chow $(6.8 \%(\mathrm{w} / \mathrm{w})$ fat. Rats on the olive oil- and corn oil-supplemented diets produced milk that had significantly lower concentrations of total fat and of C8:0 - C18:0 fatty acids and higher concentrations of C18:1 - C18:3 acids compared to the low-fat diet, chow, or the coconut oil-supplemented diets. Compared with the low-fat control diet, all the other dietary regimes suppressed overall fatty acid synthesis in both the lactating mammary gland and liver, with the highest suppression being produced by the olive oil- and corn oil-supplemented diets on mammary fatty acid synthesis. Measurements of the total activity in the mammary gland of the rate-limiting enzyme, acetyl-CoA carboxylase, and of the proportions of the polymeric (active) and protomeric (inactive) forms of this enzyme, showed that the total activity decreased in parallel with the overall rate of fatty acid synthesis. This trend was, however, not noticed for fatty acid synthetase (another lipogenic enzyme). By contrast, a constant proportion of polymeric to protomeric forms was maintained at mid-lactation irrespective of the diet, indicating a possible role of prolactin in mammary gland acetyl-CoA carboxylase polymerization. This study, therefore, showed that the fatty acid composition of the diet as well as hormones involved in lactation may affect mammary gland and liver fatty acid synthesis, through a modification of the rate limiting enzyme of fatty acid synthesis - acetyl-CoA carboxylase.

Key words: Acetyl-CoA carboxylase, milk fat, lipogenesis 


\section{INTRODUCTION}

Diet has a profound effect on de novo fatty acid synthesis in the mammary gland, brown and white adipose tissues as well as the liver $[1,2,3,4]$. In these cases, the rate of fatty acid synthesis is significantly altered by the amount of carbohydrate or fat present in the diet [5-6]. The first committed and rate determining step of fatty acid biosynthesis is the conversion of ATP, acetyl-CoA and $\mathrm{HCO}_{3}{ }^{-}$to ADP, orthophosphate and malonyl-CoA, catalysed by the enzyme acetyl-CoA carboxylase (E.C 6.4.1.2) [7 - 8]. This multicomponent enzyme, which contains a biotin carboxylase activity, a biotin carboxyl carrier protein, and a carboxyltransferase functionality, has major and minor subunits of $M_{r} 265,000$ and 280,000 respectively [9 - 10]. This enzyme has an absolute requirement for citrate or isocitrate for activity and is regulated by both allosteric and covalent modification [11 - 12]. It is present in both the cytosol and mitochondria, with the latter serving as a reservoir to maintain a normal concentration of cytosolic acetyl-CoA carboxylase [13].

The mammary gland is the sole organ for providing nutrients for nursing animals. Early researchers have shown that first week of growth performance affects future growth performance $[14,15]$ and that the post weaning growth performance depends on the pre-weaning growth [16]. The pre-weaning growth depends on the lipid composition of the milk produced in the mammary gland. Reduction of dietary fat is accompanied by reduced development of the litter and pup weights during lactation while pups of highfat diet dams grew faster $[17,18]$. While high fat diets are necessary during pregnancy and lactation in most animals, there is a need to regulate the size of lipid stores in the adipose tissue, accumulating enough to meet possible demands, but not too much that they compromise mobility and increase the vulnerability to predation.

The present study was designed to investigate the effect of feeding triacylglycerols on milk fat composition, lipogenesis and polymer-protomer transition of acetyl-CoA carboxylase in rat mammary gland.

\section{MATERIALS AND METHODS}

Corn oil, coconut oil and olive oil were purchased locally. The mineral (AIN 76) and vitamin (AIN 76A) premixes were obtained from ICN Biomedicals, Aurora, Ohio, USA. Biochemicals were from Sigma, Poole, UK and radio-chemicals were from Amersham International plc, Aylesbury, UK. Rat chow pellet was obtained from E. Dixon and Sons Ltd., Ware, UK.

\section{Animals and housing}

Forty mature virgin female $(160$ - $180 \mathrm{~g})$ and ten mature male $(160$ - $200 \mathrm{~g})$ Lister Hooded rats were obtained from Harlan Olac Breeding Centre, Bicester, UK. On arrival, the animals were caged separately and maintained on a cycle of 12 hours light $(7.00$ to $19.00 \mathrm{~h})$ and 12 hours dark (19.00 to $7.00 \mathrm{~h})$. A single male and a female were mated seven days after arrival. The males were separated from the females once a vaginal plug was observed and were used for subsequent mating with other females.

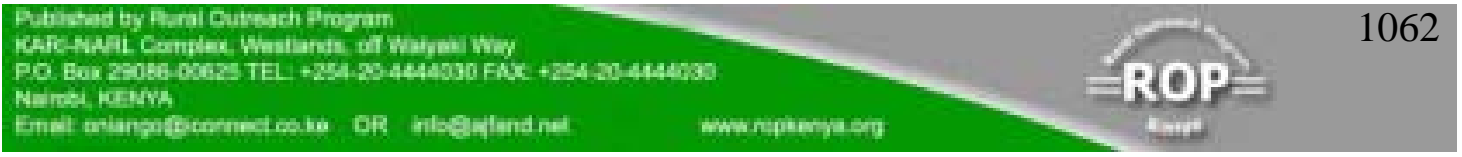




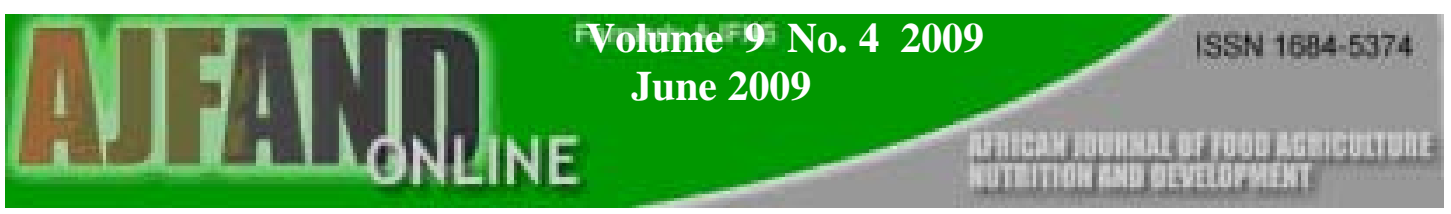

Between 10 and 24 hours post partum, litter sizes were increased or reduced to between 7 and 10 by redistribution of pups.

\section{Formulation of experimental diets}

The rats were then fed for six weeks (during pregnancy to mid-lactation) either a lowfat $0.5 \%(\mathrm{w} / \mathrm{w})$ corn oil) semi-synthetic control diet, chow $(6.8 \%(\mathrm{w} / \mathrm{w})$ fat), a low fat diet or one of three high-fat diets made by adding $200 \mathrm{~g}$ of corn oil, olive oil or coconut oil to $800 \mathrm{~g}$ of ground chow. The control low fat and the three high fat diets had similar energy content, which was higher than that of chow.

\section{Procedure of milking rats}

Between $24.00 \mathrm{~h}$ and $2.00 \mathrm{~h}$ on days 12 - 14 post partum, rats were separated from their pups, anaesthetized using diethyl ether and given a subcutaneous injection of 1 unit of oxytocin to produce contraction of the smooth muscle of the mammary gland, thereby stimulating the milk ejection reflex. When the effects of the anaesthesia were no longer apparent, the mothers were allowed to feed their young for 1 hour. The rats were then re-anaesthetised with diethyl ether and 0.5 to $1.5 \mathrm{ml}$ of milk collected from the mammary gland by gentle manual expression.

\section{Measurement of milk fat content and fatty acid composition}

Fats were extracted from the milk, methylated and the methyl esters of fatty acids prepared and analyzed by gas-liquid chromatography [19 - 20].

\section{Preparation of nuclear-free and cytosolic fractions of mammary gland}

After the rats had been milked, they were killed by cervical dislocation. The inguinal mammary glands were excised, washed with ice-cold $0.25 \mathrm{M}$ sucrose, and immediately stored in liquid $\mathrm{N}_{2}$. The time between killing the rats and transferring the tissue to liquid $\mathrm{N}_{2}$ was between 1 and 3 minutes.

Frozen portions of mammary gland ( $1 \mathrm{~g}$ wet weight) were ground and then homogenized at $4^{\circ} \mathrm{C}$ in $5 \mathrm{ml}$ Tris/ $\mathrm{HCl}$ buffer $(10 \mathrm{mM})$, pH 7.4 containing $0.25 \mathrm{M}$ sucrose, $1 \mathrm{mM}$ EDTA, $15 \mathrm{mM}$ 2-mercaptoethanol. The nuclear fraction was removed by centrifugation at $500 \mathrm{~g}$ for 30 minutes at $4^{\circ} \mathrm{C}$, and after removing the floating fat layer, portions of the nuclear-free homogenate were either stored at $-70^{\circ} \mathrm{C}$ or further centrifuged at $100,000 \mathrm{~g}_{\mathrm{av}}$ for 90 minutes to prepare the cytosol fraction which was stored at $-70^{\circ} \mathrm{C}$. The concentration of protein in the different homogenate fractions was measured by protein-dye binding, using bovine serum albumin as standard [21].

\section{Determination of fatty acid synthetase activity}

The activity of fatty acid synthetase in the cytosolic fraction of lactating mammary gland homogenates was measured spectrophotometrically [22]. The reaction was linear for up to 6 minutes when 150 - $180 \mathrm{mg}$ of cytosolic protein was used. Control assays contained no cytosolic protein.

\section{Determination of total acetyl-CoA carboxylase activity}

The total activity of acetyl-CoA carboxylase in the nuclear-free homogenate and in the cytosolic fraction of lactating mammary gland was measured by a method based on the

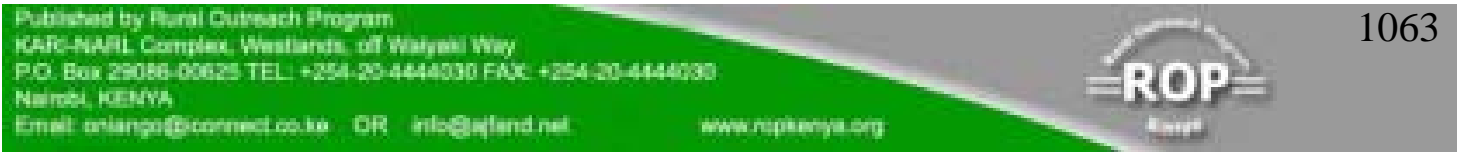




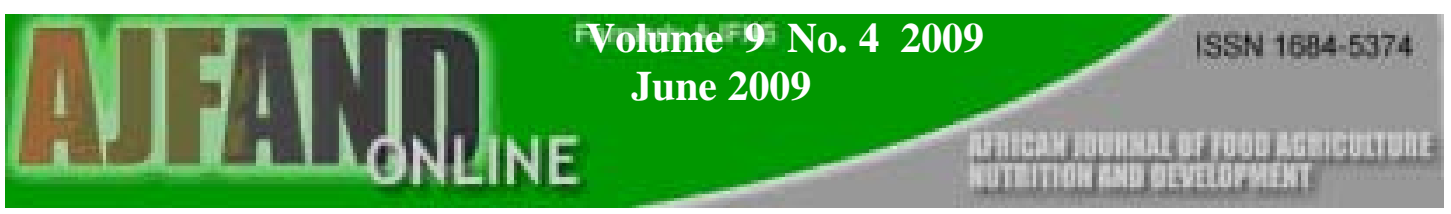

incorporation of $\mathrm{H}^{14} \mathrm{CO}_{3}{ }^{-}$into malonyl-CoA [23]. Assays were done in triplicate, as were control assays for residual $\mathrm{H}^{14} \mathrm{CO}_{3}{ }^{-}$in which $0.6 \mathrm{M} \mathrm{HCl}$ was added before the substrate mixture.

Measurement of proportions of active and inactive forms of acetyl-CoA crboxylase The proportion of polymeric (active) and of the protomeric (inactive) forms of acetylCoA carboxylase in the nuclear-free and cytosolic fractions of lactating rat mammary gland were measured by preparing homogenates of tissue, as described above, in the absence (that is with both the active polymeric and the inactive protomeric forms present) or in the presence (that is with only the active polymeric form present) of 400 $\mathrm{mg}$ avidin [23]. The avidin-treated homogenates were incubated at $4^{\circ} \mathrm{C}$ for 1 minute with homogenization medium that contained biotin $(4 \mathrm{mg} / \mathrm{ml})$ to remove unbound avidin, and the nuclear-free and cytosolic fractions then prepared as described above.

\section{Measurement of in vivo rates of mammary and hepatic fatty acid synthesis}

Lactating rats were separated from their litter at $0.30 \mathrm{~h}$ or at $9.30 \mathrm{~h}$ and injected intraperitoneally with ${ }^{3} \mathrm{H}_{2} \mathrm{O}(5 \mathrm{mCi}$ in $0.5 \mathrm{ml})$. They were then allowed to feed their young for 1 hour before being killed by cervical dislocation. The entire mammary glands and liver were removed, and the lipids extracted and saponified to measure the rates of fatty acid synthesis [9]. Blood was collected from the aorta into heparinized tubes to measure the specific radioactivity of ${ }^{3} \mathrm{H}_{2} \mathrm{O}$ in the plasma.

\section{Statistical treatment of results}

Results are presented as mean values with the standard error (SE) of the mean. Statistical significance was determined by Student's t-test for unpaired samples.

\section{RESULTS}

\section{Effect of diets on contentnd fatty acid composition of milk fat}

Rats fed either the $20 \%(\mathrm{w} / \mathrm{w})$ olive oil-supplemented diet or the $20 \%(\mathrm{w} / \mathrm{w})$ corn oilsupplemented diet produced milk with significantly lower total fat concentrations $(p<0.05)$ than rats fed the low-fat $(0.5 \%(\mathrm{w} / \mathrm{w})$ corn oil) control diet or with chow $(6.8 \%(\mathrm{w} / \mathrm{w})$ fat (Table 1). This lower total milk fat content was paralleled by a significantly lower concentration $(p<0.05)$ of C8:0 - C18:0 fatty acids, and a higher concentration of C18:1 - C18:3 fatty acids. By contrast, the concentrations of milk fat and of these two groupings of fatty acids in the milk of rats fed the $20 \%(\mathrm{w} / \mathrm{w}$ ) coconut oil-supplemented diet were not significantly different from those in the milk of rats on the control diet and chow.

\section{Effects of diets on in vivo rates of fatty acid synthesis in the mammary gland and liver}

Rats fed the olive oil-supplemented, corn oil-supplemented and coconut oilsupplemented diets or with chow had significantly lower $(p<0.001, p<0.001$ and $p<0.05$, respectively) rates of mammary fatty acid synthesis in vivo compared with rats fed the $0.5 \%(\mathrm{w} / \mathrm{w})$ corn oil control diet (Table 2). By contrast the rate was significantly higher $(p<0.01)$ in rats fed the coconut oil-supplemented diet compared with those fed the olive oil-supplemented or the corn oil-supplemented diets. These

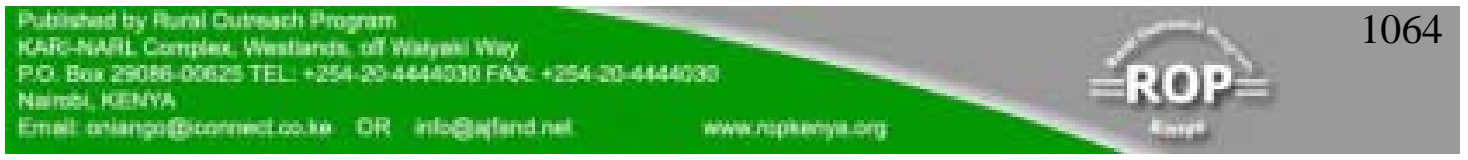


differences were only observed when the measurements in vivo were made using mammary tissue prepared from rats sacrificed between $0.30 \mathrm{~h}-2.30 \mathrm{~h}$ (when rates of mammary fatty acid synthesis are at a maximum), and not when the tissue was prepared from rats sacrificed between $9.30 \mathrm{~h}-11.30 \mathrm{~h}$.

Rates of hepatic fatty acid synthesis in vivo were similar in rats fed each of the three oilsupplemented diets and were significantly lower than those observed with the control low fat diet $(p<0.001)$ or with chow $(p<0.05)$ (Table 2$)$.

\section{Effect of diet on lactating mammary gland and hepatic fatty acid synthetase activity}

The activity of lactating mammary gland fatty acid synthetase was not significantly altered by any of the diets. The mean (SE) activities were 4.60(0.68), 4.39(0.41), $4.28(0.20)$ and $4.38(0.48)$ nmol NADPH oxidized per min per $\mathrm{mg}$ protein in the mammary gland of rats fed the low-fat control diet, the coconut oil-, olive oil- and corn oil-enriched diets, respectively. The activity of fatty acid synthetase in the liver of 14day lactating rats was significantly higher than in the corresponding mammary gland. The hepatic activities were, however, not altered by the different dietary regimes.

\section{Effect of diet on lactating mammary gland acetyl-CoA carboxylase activity}

The total activity of acetyl-CoA carboxylase in the mammary gland cytosol of lactating rats fed the $0.5 \%(\mathrm{w} / \mathrm{w})$ corn oil semi-synthetic diet (control group) was significantly higher $(\mathrm{p}<0.05)$ than for rats fed chow or chow supplemented with $20 \%(\mathrm{w} / \mathrm{w})$ coconut oil. The activities for the control rats were also significantly $(\mathrm{p}<0.01)$ higher than activities in rats fed chow supplemented with $20 \%(\mathrm{w} / \mathrm{w})$ corn oil or olive oil. Although these dietary dependent decreases in the activities of acetyl-CoA carboxylase parallel decreases in the rate of overall fatty acid synthesis, the two sets of changes are not directly related. Chow, for example, causes a 2-fold decrease in overall fatty acid synthesis, but only a 1.5-fold decrease in the activity of acetyl-CoA carboxylase activity. The activities of acetyl-CoA carboxylase for rats on the other diets are also not altered to the same extent as the overall fatty acid synthesis. Although this lack of correlation between suppression of mammary acetyl-CoA carboxylase activity and fatty acid synthesis may not be statistically significant, it raises the possibility that fatty acid synthesis is only partially regulated by acetyl-CoA carboxylase in the cytosolic fraction. It has been shown that a number of factors modify the activity of acetyl-CoA carboxylase converting it between the inactive protomeric and active polymeric forms $[24,25,26]$.(Table 3).

\section{Effect of diet on the presence and activity of the active and inactive forms of acetyl-CoA carboxylase}

The activity of acetyl-CoA carboxylase in mammary gland nuclei-free homogenates prepared in the presence and absence of avidin indicates that polymerization/ depolymerization are not solely responsible for the modification of activity (Table 4). Avidin specifically binds to the protomeric (inactive) acetyl-CoA carboxylase preventing polymerization (activation) by citrate. The polymeric form of the enzyme is, however, resistant to avidin binding. When mammary gland was therefore homogenized in the presence or absence of avidin, followed by the presence of citrate, a

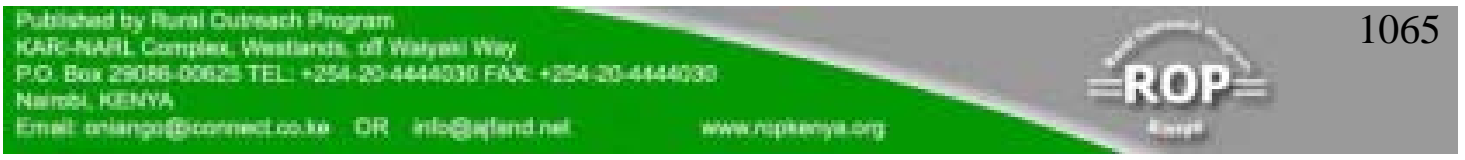


ratio of the active to inactive form could be be obtained. With each diet, the activity of acetyl-CoA carboxylase in the nuclei-free homogenate measured both in the presence and absence of avidin was significantly higher than in the supernantant $\left(100,000 \mathrm{~g}_{\mathrm{av}} \mathrm{x} 90\right.$ $\mathrm{min}$ ) fraction, which indicates that some of the acetyl-CoA carboxylase activity had been lost by co-sedimentation of the polymeric (active) acetyl-CoA carboxylase with sub-cellular organelles during the preparation of this fraction. The activity of acetylCoA carboxylase in the $100,000 \mathrm{~g}_{\mathrm{av}}$ x $90 \mathrm{~min}$ fraction prepared in the presence of avidin. was high in rats fed the semi-synthetic diet supplemented with $0.5 \%(\mathrm{w} / \mathrm{w})$ corn oil. Corn oil and olive oil supplementation $(20 \% \mathrm{w} / \mathrm{w})$ significantly $(\mathrm{p}<0.001)$ reduced this activity. There was a slight suppression of acetyl-CoA carboxylase activity in this fraction as a result of feeding chow or chow supplemented with $20 \%$ (w/w) coconut oil. This indicates that although there is co-sedimentation of polymeric acetyl-CoA carboxylase with sub-cellular organelles, the supernatant still contains protomeric as well as low molecular weight polymeric forms of the enzyme which are activated by the presence of citrate during assay. This hypothesis is substantiated by the fact that when the $100,000 \mathrm{~g}_{\mathrm{av}} \times 90 \mathrm{~min}$ fraction is prepared from mammary gland homogenized in the presence of avidin (protomer not activated by citrate during assay), the activities of acetyl-CoA carboxylase were very low (Table 4). This low activity probably results from the intermediate molecular weight polymers which were resistant to avidin inactivation. Unlike the activities in homogenates prepared in the absence of avidin which were altered by the high fat diets, the activities in the $100,000 \mathrm{~g}_{\mathrm{av}} \times 90 \mathrm{~min}$ fraction from mammary gland homogenized in the presence of avidin were not affected by the different diets.

\section{DISCUSSION}

This study first examined differences in the concentration and fatty acid composition of milk fat from rats that had been fed for six weeks up to mid lactation on diets enriched with three different triacylglycerols. Coconut oil is rich in medium-chain fatty acids (C8:0; 5-10\%; C10:0; 5-10\%, C12:0; 43-53\%; C14:0; 15-21\%; C16:0; 7-11\%), whilst olive oil contains predominantly palmitic and oleic acids (7-16\% and 65-85\%, respectively) and corn oil contains mainly palmitic, oleic and linoleic acids (8-19\%, 19$50 \%$ and $34-62 \%$, respectively). Previous work showed that short-term (8 days) feeding of lactating rats with diets containing different triacylglycerols produced a milk fatty acid composition similar to that of the dietary triacylglycerols [9]. We are not aware of studies that have examined the long-term changes brought about by dietary triacylglycerols on milk fat content and fatty acid composition or the mechanism by which such an effect might be brought about over the period of six weeks during pregnancy to mid-lactation.

\section{The role of acetyl-CoA carboxylase in the dietary control of lactating mammary gland fatty acid synthesis}

The presence of acetyl-CoA carboxylase activity in the cytosol is consistent with the site of de novo fatty acid synthesis. With each of the five diets used however the total activity (that is in the absence of avidin) of the enzyme was much lower $(\mathrm{p}<0.05)$ in the mammary cytosol than in the nuclear-free homogenate (Table 3). This is probably due to sedimentation of the polymeric active filaments of acetyl-CoA carboxylase by the

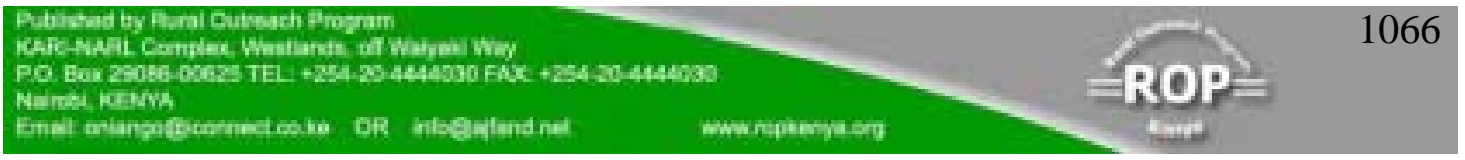


high centrifugation $\left(100,000 \mathrm{~g}_{\mathrm{av}}\right)$ used to prepare the cytosol, thereby decreasing the activity of this enzyme in the cytosol. A similar effect had been reported for the activity of the enzyme sub-cellular fractions of lactating rabbit mammary gland [27 - 28]. The lower total activity of the enzyme in the mammary cytosol of rats fed the three high-fat diets indicates the presence of a lower proportion of inactive protomeric enzyme which was then activated after the polymeric form of the enzyme was removed by centrifugation.

In the absence of avidin in the assay mixture, the activity of acetyl-CoA carboxylase is a measure of both the active polymeric and the activated protomeric since the inactive protomers are able to polymerise into the active form in the presence of citrate in the assay mixture. In the presence of avidin, which binds to the biotin moiety of acetylCoA carboxylase and inactivates the enzyme, inactive protomers cannot reform polymers even with citrate present in the assay mixture. It was, therefore, possible in this study to measure the effect of the experimental diets on the relative proportions in both the nuclear-free homogenate and in the cytosol of acetyl-CoA carboxylase in the active polymeric form compared with the inactive protomeric form. In the nuclear-free homogenate, the proportion of the total enzyme in the active form (i.e. +avidin / avidin) was approximately the same $(60-72 \%)$ for all the five different diets (Table 3$)$. This proportion was constant even with rats fed the olive oil- and the corn oil-enriched diets in which the total activity of the enzyme was significantly lower than with the other diets. This decrease in total activity in response to the olive oil- and corn oilenriched diets but not to the coconut oil-enriched diet could be due to the inhibitory effect of long-chain unsaturated fatty acyl-CoA on the synthesis and/or stability of acetyl-CoA mRNA, similar to that observed in the weaned rats [29].

\section{The role of the diet on milk fat synthesis}

Milk from rats fed the low-fat control diet had a significantly higher total fat content than that from rats fed the olive oil- and corn oil-enriched diets (Table 1). This indicates significantly higher rates of de novo mammary fatty acid synthesis in rats fed the low-fat control diet, since the contribution of dietary fatty acids is negligible, which was reflected by the high concentrations of C8:0 - C16:0 fatty acids which are readily synthesized by the lactating mammary gland. The presence of the C18:1-C18:3 fatty acids in the milk of rats fed the low-fat diet therefore suggests their hepatic synthesis by chain elongation and de-saturation within the mammary gland, which are known to be active in the lactating rat [11].

There was no difference between the total fat concentrations of the milk obtained from rats fed the three oil-supplemented diets (Table 1). The C8:0 - C10:0 fatty acids released by the digestion of coconut oil are transported much faster, via the portal circulation, than the predominantly longer-chain fatty acids released by the digestion of either olive oil or corn oil which are transported via the lymph. The concentration of the milk fatty acids C8:0 - C16:0 that are synthesized de novo within the mammary gland was significantly higher with rats fed the low-fat control diet and the coconut oilenriched diet than with the olive oil- or corn oil-enriched diets. As expected the concentration of C18:1 - C18:3 fatty acids in milk fat was higher with the olive oil- and corn oil-supplemented diets. This difference resulted from both transportation of

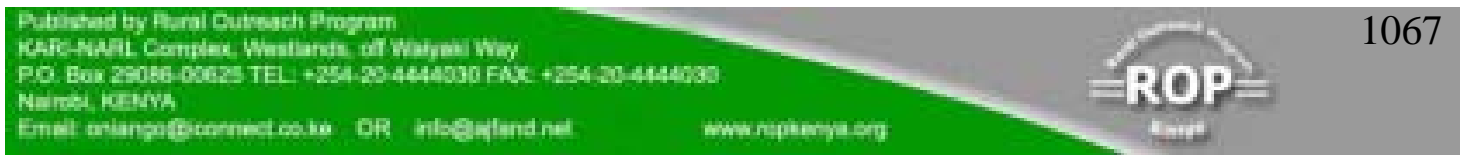


dietary fatty acids into milk fat and a suppression of de novo fatty acid synthesis within the mammary gland. Hepatic fatty acid synthesis was, however, not different in rats fed the coconut oil-enriched diet compared with the olive oil- or corn oil-enriched diets, indicating that the contribution of the liver to C8:0 - C16:0 milk fatty acids was minimal.

\section{CONCLUSION}

Fat synthesis in lactating rat mammary gland seems to be under a very fine control in which the diet, especially the triacylglycerol content and composition of the lactating animal play a very important role. The activity of acetyl-CoA carboxylase, the ratedetermining enzyme in de novo fatty acid synthesis plays an important role in this control process.

The need for milk to be a rich energy source for the neonate makes such a control necessary. In rats fed on diets deficient in fatty acids, the mammary gland and liver are able to synthesize fatty acids which are transferred into the milk. On the other hand, in triacylglycerol rich diets there is transfer of dietary triacylglycerols into milk triacylglycerols which are subsequently available to the neonate. In both situations, therefore, the neonate is supplied with adequate lipids from the milk. Dietary fat is essential in litter development, while high fat diets are necessary during pregnancy and lactation in most animals. This might have applications in human nutrition and health, where the quality of milk available to babies could be affected by the fat intake of the mother, thus affecting the growth and performance of the child. On the other hand, in farm animals the quality of milk as well as milk-derived products could be affected by the nutrient intake of the animal. 


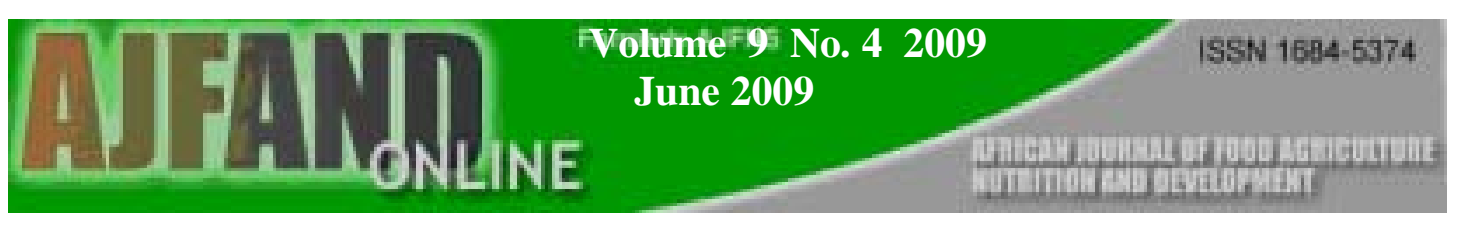

Table 1: The effect of diet on milk fat content and composition

\begin{tabular}{|l|l|l|l|}
\hline \multirow{2}{*}{\multicolumn{1}{|c|}{ Diet }} & \multicolumn{2}{c|}{$\begin{array}{c}\text { Concentration of fatty acids in milk } \\
\text { (mg/ml) }\end{array}$} \\
\cline { 2 - 4 } & $\begin{array}{c}\text { Total fat content } \\
(\mathrm{mg} / \mathrm{ml})\end{array}$ & $\begin{array}{c}\text { C8:0-C12:0 fatty } \\
\text { acids }\end{array}$ & $\begin{array}{c}\text { C16:O Palmitic } \\
\text { acid }\end{array}$ \\
\hline $\begin{array}{l}\text { Semi-synthetic } \\
\text { containing 0.5\% } \\
\text { (w/w) corn oil }\end{array}$ & $93 \pm 12$ & $18 \pm 3$ & $48 \pm 11$ \\
\hline $\begin{array}{l}\text { Chow (8\%, w/w } \\
\text { fat) }\end{array}$ & $80 \pm 6$ & $12 \pm 2^{*}$ & $42 \pm 9$ \\
\hline $\begin{array}{l}\text { Chow } \\
\text { supplemented with } \\
20 \% \text { (w/w) corn oil }\end{array}$ & $70 \pm 10^{*}$ & $9 \pm 4^{* *}$ & $18 \pm 8^{* *}$ \\
\hline $\begin{array}{l}\text { Chow } \\
\text { supplemented with } \\
\text { 20\% (w/w) coconut } \\
\text { oil }\end{array}$ & $79 \pm 15$ & $16 \pm 3$ & $36 \pm 10$ \\
\hline $\begin{array}{l}\text { Chow } \\
\text { supplemented with } \\
20 \% \text { (w/w) olive oil }\end{array}$ & $63 \pm 11^{*}$ & $7 \pm 2^{* *}$ & $21 \pm 4^{* *}$ \\
\hline
\end{tabular}

Lactating rats were fed the different diets for 1 week before pregnancy, and until 14 days post partum. Fat content and composition was determined by gas liquid chromatography. Values are means \pm sem. Significant differences were by comparison with rats fed the $0.5 \%(w / w)$ semi-synthetic diet. ${ }^{*} p<0.05 ; * * p<0.01$ 
Table 2: The effect of long- term feeding on overall fatty acid synthesis in the mammary gland and liver

\begin{tabular}{|l|l|l|}
\hline \multirow{2}{*}{ Diet } & \multicolumn{2}{|c|}{$\begin{array}{c}\text { Rate of lipogenesis } \\
\left(\boldsymbol{\mu m o l}{ }^{\mathbf{3}} \mathbf{H}_{\mathbf{2}} \mathbf{O} \text { incorporated per gram wet }\right. \\
\text { weight tissue per hour) }\end{array}$} \\
\cline { 2 - 3 } & \multicolumn{1}{|c|}{ Mammary Gland } & \multicolumn{1}{c|}{ Liver } \\
\hline $\begin{array}{l}\text { Semi-synthetic } \\
\text { containing 0.5\% } \\
\text { (w/w) corn oil }\end{array}$ & $124 \pm 16$ & $78 \pm 11$ \\
\hline Chow (8\%,w/w fat) & $62 \pm 10^{*}$ & $49 \pm 15^{* *}$ \\
\hline $\begin{array}{l}\text { Chow supplemented } \\
\text { with 20\% (w/w) } \\
\text { corn oil }\end{array}$ & $28 \pm 10^{* * *}$ & $28 \pm 10^{* *+}$ \\
\hline $\begin{array}{l}\text { Chow supplemented } \\
\text { with 20\% (w/w) } \\
\text { coconut oil }\end{array}$ & $80 \pm 8^{*}$ & $34 \pm 6^{* *}$ \\
\hline $\begin{array}{l}\text { Chow supplemented } \\
\text { with 20\% (w/w) } \\
\text { olive oil }\end{array}$ & $26 \pm 8^{* * *}$ & $32 \pm 9^{* *}$ \\
\hline
\end{tabular}

Rates of fatty acid synthesis were determined in vivo. Values are means \pm sem. Statistically significant differences were either by comparison with rats fed the $0.5 \%$ $(w / w)$ semi-synthetic diet. $* p<0.05 ; * * p<0.01 ; * * *<0.001$ or between chow fed rats and rats fed the high fat diets ${ }^{+} p<0.05$. 


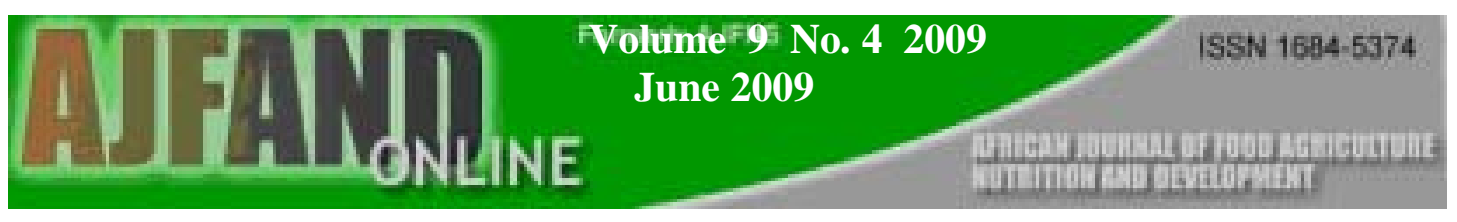

Table 3: The effect of diet on acetyl-CoA carboxylase and fatty synthetase activities in the mammary gland and liver of lactating rats

\begin{tabular}{|c|c|c|c|c|}
\hline \multirow[t]{2}{*}{ Diet } & \multicolumn{2}{|c|}{$\begin{array}{c}\text { Acetyl-CoA carboxylase } \\
\text { activity } \\
\text { (nmol } \mathrm{H}^{14} \mathrm{CO}_{3} \text { incorporated / min/ } \\
\text { mg protein) }\end{array}$} & \multicolumn{2}{|c|}{$\begin{array}{c}\text { Fatty Acid synthetase activity } \\
\text { (nmol NADPH oxidized/min/mg } \\
\text { protein) }\end{array}$} \\
\hline & $\begin{array}{l}\text { Mammary } \\
\text { Gland }\end{array}$ & Liver & $\begin{array}{l}\text { Mammary } \\
\text { Gland }\end{array}$ & Liver \\
\hline $\begin{array}{l}\text { Semi-synthetic } \\
\text { containing } \\
0.5 \%(\mathrm{w} / \mathrm{w}) \\
\text { corn oil }\end{array}$ & $9.8 \pm 0.4$ & $4.1 \pm 0.6$ & $4.7 \pm 0.4$ & $8.3 \pm 0.5$ \\
\hline $\begin{array}{l}\text { Chow }(8 \%, \\
\text { w/w fat) }\end{array}$ & $6.4 \pm 0.6^{*}$ & $2.9 \pm 0.8$ & $3.9 \pm 1.1$ & $7.5 \pm 1.3$ \\
\hline $\begin{array}{l}\text { Chow } \\
\text { supplemented } \\
\text { with } 20 \% \\
\text { (w/w) corn oil }\end{array}$ & $3.1 \pm 0.3 * * *$ & $2.0 \pm 0.3^{*}$ & $4.5 \pm 0.4$ & $3.8 \pm 1.2^{*}$ \\
\hline $\begin{array}{l}\text { Chow } \\
\text { supplemented } \\
\text { with } 20 \% \\
\text { (w/w) coconut } \\
\text { oil }\end{array}$ & $6.3 \pm 0.7 *$ & $1.7 \pm 0.3 * *$ & $4.8 \pm 0.3$ & $6.4 \pm 0.9$ \\
\hline $\begin{array}{l}\text { Chow } \\
\text { supplemented } \\
\text { with } 20 \% \\
\text { (w/w) olive oil }\end{array}$ & $3.0 \pm 0.2 * * *$ & $1.6 \pm 0.3 * *$ & $4.4 \pm 0.2$ & $7.8 \pm 1.1$ \\
\hline
\end{tabular}

Values are means \pm sem. Statistically significant differences in acetyl CoA activity in either the mammary gland or the liver were by comparison with rats fed the semisynthetic diet. $* p<0.05 ; * * p<0.01 ; * * * p<0.001$ 


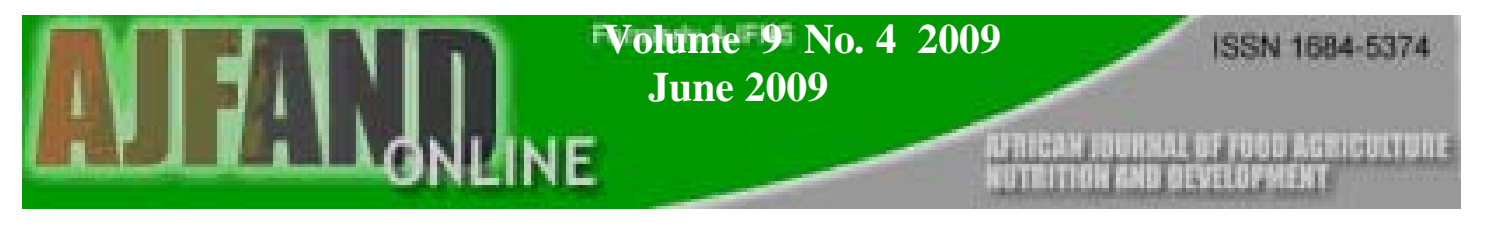

Table 4: The effect of diet on mammary gland acetyl-CoA carboxylase activation

\begin{tabular}{|c|c|c|c|c|}
\hline \multirow[b]{2}{*}{ Diet } & \multicolumn{4}{|c|}{$\begin{array}{c}\text { Acetyl-CoA carboxylase activity } \\
\text { (nmol } \mathrm{H}^{14} \mathrm{CO}_{3} \text { incorporated / } \mathrm{min} / \mathrm{mg} \text { protein) }\end{array}$} \\
\hline & $\begin{array}{c}\text { PFS } \\
\text { (No avidin) }\end{array}$ & $\begin{array}{c}\text { PFS } \\
\text { (with avidin) }\end{array}$ & $\begin{array}{c}\text { NFH } \\
\text { (No avidin) }\end{array}$ & $\begin{array}{c}\mathrm{NFH} \\
\text { (with avidin) }\end{array}$ \\
\hline $\begin{array}{l}\text { Semi-synthetic } \\
\text { containing } \\
0.5 \%(\mathrm{w} / \mathrm{w}) \\
\text { corn oil }\end{array}$ & $9.8 \pm 0.4$ & $2.4 \pm 0.8$ & $18.6 \pm 1.9$ & $12.3 \pm 2.4$ \\
\hline $\begin{array}{l}\text { Chow }(8 \%, \\
\text { w/w fat) }\end{array}$ & $6.4 \pm 0.6^{*}$ & $2.0 \pm 1.0 * *$ & $12.1 \pm 4.2$ & $8.0 \pm 3.2$ \\
\hline $\begin{array}{l}\text { Chow } \\
\text { supplemented } \\
\text { with } 20 \% \\
\text { (w/w) corn oil }\end{array}$ & $3.1 \pm 0.3 * * *$ & $1.4 \pm 0.6^{*}$ & $6.1 \pm 0.9 * *$ & $3.9 \pm 0.5^{*}$ \\
\hline $\begin{array}{l}\text { Chow } \\
\text { supplemented } \\
\text { with } 20 \% \\
\text { (w/w) coconut } \\
\text { oil }\end{array}$ & $6.3 \pm 0.7 *$ & $1.8 \pm 0.6$ & $14.5 \pm 2.2$ & $10.5 \pm 1.1$ \\
\hline $\begin{array}{l}\text { Chow } \\
\text { supplemented } \\
\text { with } 20 \% \\
\text { (w/w) olive oil }\end{array}$ & $3.0 \pm 0.2 * * *$ & $1.1 \pm 0.5 * * *$ & $8.5 \pm 1.5^{* *}$ & $5.1 \pm 0.8^{* *}$ \\
\hline
\end{tabular}

Mammary gland was homogenized in the absence or presence of avidin. Particle free supernatant (PFS) 100,000 $g_{a v} x$ 90min and nuclei free homogenates (NFH) 15,000 $g_{a v} x$ $60 \mathrm{~min}$ were used to measure acetyl-CoA carboxylase activity. Values are means \pm sem. Statistically significant differences were between the same type of assay, i.e. with or without avidin compared to results with rats fed the $0.5 \%(w / w)$ corn oil semi-synthetic diet. ${ }^{*} p<$ $0.05 ; * *<0.01 ; * * * p<0.001$ 


\section{REFERENCES}

1. Bauman D E, Perfield II J W, Harvatine K J and LH Baumgard Regulation of Fat Synthesis by Conjugated Linoleic Acid: Lactation and the Ruminant Model.J. Nutr. 2008; 138(2): 403 - 409.

2. Fitzgerald AC, Annen-Dawson EL, Baumgard LH and R J Collier Evaluation of Continuous Lactation and Increased Milking Frequency on Milk Production and Mammary Cell Turnover in primiparous Holstein Cows. $J$. Dairy Sci. 2007; 90(12): 5483 - 5489.

3. Hurtaud A and JL Peyraud Effects of Feeding Camelina (Seeds or Meal) on Milk Fatty Acid Composition and Butter spreadability. J. Dairy Sci.,2007; 90(11): $5134-5145$.

4. Williamson DH, Munday MR, Jones RG, Roberts AF and AJ Ramsey Short-term dietary regulation of lipogenesis in the lactating mammary gland of the rat. Adv Enz Regul. 1983; 21: 135-45.

5. Pallardo FV and DH Williamson Comparison of the flux of carbon to hepatic glycogen deposition and fatty acid and cholesterol synthesis on re-feeding rats fed ad libitum or meal-fed rats with a chow-diet meal. Biochem J. 1989; 257: 607-610.

6. Grigor MR and KR Gain The effect of starvation and refeeding on lipogenic enzymes in mammary glands and livers of lactating rats. Biochem J. 1983; 216: 515-518.

7. Iritani N, Nishimoto N, Katsurada A and H Fekuda Regulation of epaticlipogenic enzyme gene expression by diet quantity in rats fed a fat- free, high carbohydrate diet. J. Nutr. 1992; 12: 28-36.

8. Witters LA, Gao G, Kemp BE and B Quistorff Hepatic 5'-AMP-Activated Protein Kinase: Zonal Distribution and Relationship to Acetyl-CoA Carboxylase Activity in Varying Nutritional States. Arch Biochem Biophy. 1994; 308(2): 413-419.

9. Neville MC and MF Picciano Regulation of milk lipid secretion and composition. Annual Review of Nutrition. 1997; 17: 159-184.

10. Waldrop GL, Rayment I and HM Holden Three-dimensional structure of the biotin carboxylase subunit of acetyl-CoA carboxylase. Biochem. 1994; 33: 10249-1056.

11. Winz R, Hess $\mathbf{D}$, Aebersold $\mathbf{R}$ and $\mathbf{R}$ Brownsey Unique structural features and differential phosphorylation of the 280-kDa component (isozyme) of rat liver acetyl-CoA carboxylase. J Biol. Chem. 1994; 269: 14438-14445.

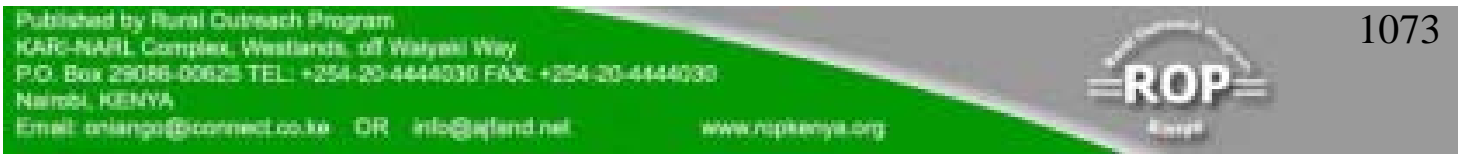


12. Carlson $\mathbf{C}$ and $\mathbf{K}$ Kim Regulation of hepatic acetyl-CoA carboxylase by phosphorylation and dephosphorylation. J Biol. Chem. 1973; 248: 378-380.

13. Mohamed AH, Huang WY, Venkatachalam KV and SJ Wakil Isolation and characterization of a novel acetyl-CoA carboxylase kinase from rat liver. $J$ Biol Chem. 1994; 269: 6859-6865.

14. Loh TC, Foo HL, Zuina AW and BK Tan Effects of feeding fat during pregnancy and lactaion on growth performance, milk composition and very low density lipoprotein composition in rats. Mal. J. Nutr. 2002; 8: 125-135.

15. Loh TC, Dodds PF and IJ Lean Effects of weaning weight and first week growth performance postweaning on subsequent performance. J. Vet. Mal. 1998; 10: 47-50.

16. McConnell JC, Eargle JC and RC Walsort Effects of weaning weight comingling, group size and room temperature on pig performance. J. Anim. Sci. 1987; 65: 1201-1206.

17. Del Prado M, Delgado G and S Villalpando Maternal lipid intake during pregnancy and lactation alters milk composition and production and alter growth in rats. J. Nutr. 1997; 127: 456-462.

18. Ringseis R, Saal D, Müller A, Steinhart $\mathbf{H}$ and K Eder Dietary conjugated linoleic acids lower the triacylglycerol concentration in milk of lactating rats and impair the growth and increase the mortality of their suckling pups. J. Nutr. 2004; 134: 3327-3334.

19. Ha J, Daniel S, Broyles SS and KH Kim Critical phosphorylation sites for acetyl-CoA carboxylase activity. J. Biol. Chem. 1994; 269: 22162-22168.

20. Shriver BJ, Roman-Shriver C and JB Allred Depletion and repletion of biotinyl enzymes in liver of biotin-deficient rats: evidence of a biotin storage system. J. Nutr. 1993; 123(6): 1140-1149.

21. Glass RL Alcoholysis, saponification and the preparation of fatty acid methyl esters. Lipids, 1971; 6: 919-925.

22. Patton GM, Cann S, Brunengraber $\mathbf{H}$ and JM Lowenstein Separation of methyl esters of fatty acids by gas chromatography on capillary columns, including the separation of deuterated from nondeuterated fatty acids. Methods Enzymology. 1981; 72: 8-20.

23. Bradford MM A rapid and sensitive method for the quantitation of icrogram quantities of protein utilizing the principle of protein-dye binding. Anal Biochem 1976; 72: 248-254. 
24. Rudolph MC, Neville MC and SM Anderson Lipid Synthesis in Lactation: Diet and the Fatty Acid Switch. Journal of Mammary Gland Biology and Neoplasia, 2007; 12: 269-281.

25. Ki-Han K Regulation of mammalian acetyl-coenzyme a carboxylase. Annual review of nutrition, 1997; 17: 77-99.

26. Oben $\mathbf{J}$ and $\mathbf{R}$ Dils Prolactin-stimulated polymerization of acetyl-CoA carboxylase in explants of mid-pregnant rat mammary gland. J. Dairy. Res. 2001; 68: $351-355$.

27. Bauman D E and J M Griinari Regulation and nutritional manipulation of milk fat: Low-fat milk syndrome. Livest. Prod. Sci, 2001;70: 15-29.

28. Baumgard L H, Sangster JK and DE Bauman Milk fat synthesis in dairy cows is progressively reduced by increasing amounts of trans-10, cis-12 CLA conjugated linoleic acid (CLA). J. Nutr. 2001; 131:1764-1769.

29. Foufelle F, Perdereau D, Gouhot B, Ferre P and J Girard Effect of diets rich in medium-chain and long-chain triglycerides on lipogenic enzyme gene expression in liver and adipose tissue of the weaned rat. E. J. Biochem. 1992; 208: $381-387$. 